and fellow of Trinity College. He was then concerned with the physiology of the crustacean muscular system; he wrote a series of papers on the mechanism of excitation and inhibition. Later he made a very procise investigation of the mode of action of the nervo net and muscular system of Coelenterates, in particular in sea anemones. He discovered that the nerve net will only respond to a series of shocks, each of which elicits a single impulse in the net. Each group of muscles responds to a series of shocks of characteristic number and time interval. This enabled Pantin to explain the mechanism by which the animal's behaviour is controlled. He later investigated the functional anatomy of the nemertines, which were then little known in Britain. During this time he became reader in zoology, and succeeded Sir James Gray as professor in 1959 .

Among his many general writings was a paper on identification and recognition, which was a presidential address to the British Association. Pantin was also active in the Royal Society, to which he was elected in 1937, and which awarded him a Royal Medal in 1950; he had been president of the Linnean Society, and in 1963 became chairman of the Trustees of the British Museum (Natural History). He was always interested in marine biology overseas, and was recently a very active chairman of the Nuffield Unit of Tropical Animal Ecology in Uganda. Zoology at Cambridge has benefited much from his great interest and experience in the teaching of science.

\section{Professor R. M. Sievert}

Rolf Maximulian Sievert died in Stockholm on December 3 , aged seventy. He had been director of the Institute of Radiophysics of the Karolinska Institutet since 1937.

When Gösta Forsell, the founder of Swedish radiology, met Sievert, a physicist, in the United States, he persuaded him to start work in radiation physics and build up a hospital organization. In the early twenties hospitals did not standardize the amount of radiation which they administered to patients, and so Sievert and his assistants developed the Sievert condenser chambers to measure dosage. These were soon in use throughout the world. Dosage for the treatment of tumours was based on detailed measurements made on wax phantoms. Sievert was also keenly interested in radiation protection, and this resulted in his work on radiation biology, on which he became an authority.

Sievert realized the importance of international cooperation in the establishment of dose units and protection rules which were generally accepted in all countries. In 1928 he was one of the founders of the International Radiation Protection Committee, and he was later on the United Nations Scientific Commission on Radiological Protection; he was chairman in 1963-66. He was the first member with a natural science degree to be appointed professor of radiation physies at tho Karolinska Institutet, which is a medical institute. In 1944 Sievert became a member of the Royal Swedish Academy of Sciences, and in 1959 of the Academy of Engineering Sciences. During the Second World War he had taken the initiative in the formation of a research institute for defence, and he was a member of the board until 1945. His administrative talent was also used in the planning of the Geophysical Research Institute in northern Sweden. His last years were occupied with plans for the National Institute of Radiation Protection, which was ready in 1965. Sievert remained active until the last days before his death, as a chairman of committees, and he continued to take an interost in the work of his institutions.

ARne Forssberg

\section{Dr. Paul White}

Paut Whrte, senior lecturer in applied mathematies in the University of Reading, died on January 7, aged sixtytwo.
He was born and grew up in Lewisham, where he attended Colfe's Grammar School, and he went to Clare College, Cambridge, in 1922 as an Entrance Scholar. He gained a double first in mathematics and then a first in physies, and went on to undertake research in the Cavendish Laboratory under Lord Rutherford, working on the properties of $\beta$-particles and their passage through thin films. A contemporary of this time refers to "a great personal impression of brilliance". After obtaining a Ph.D., he went to Aberdeen as a Carnegie Teaching Fellow, where with G. P. Thomson he continued and extended his work to consider cathode rays.

In 1933 he went to the University of Reading. Work with Crowther and Liebmann on the interaction of $\mathrm{X}$-radiation with biological colloids and on electroosmotic effects stimulated an interest in statisties. This led to a lengthy and fruitful period of collaboration with a number of workers, particularly at the National Institute for Research in Dairying, where he provided the statistical basis for the biological work. He also worked with Bond on precise measurements of gas viscosity, and was a founder member of the British Rheologists Club. The demands of war-time teaching developed an unexpected competence in astrophysics and metoorology. After the Second World War, expansion of the University and the shortage of mathematicians led Paul White to transfer to the Department of Mathematics, with special responsibility for the development and teaching of applied mathematics. This marked the end of direct personal and individual research, but he continued to help many people in other disciplines with the mathematical aspects of their work.

White led a very full life in the University; he lived in St. Patrick's Hall, of which he was Senior Resident, sang in the Choral Society and coached an eight on the riverhe always undertook the timekeeping of the Head of the River race with enthusiasm and meticulous attention. No account of Paul White's life could bo complete without reference to his Christian faith and work. He was a truly devout man, an ardent and active Congregationalist and a staunch supporter of the Student Christian Movement. A lay preacher from his Cambridge days, he was always a welcome preacher in Congregational pulpits over a wide area.

K. W. Alten

\section{Dr. C. W. Farstad}

Christian W. Farstad, who was awarded the Gold Medal of the Entomological Society of Canada last year, died at the age of sixty, on November 18, after an operation in a Toronto hospital. Ho had made many contributions to the control of insect pests; his sawfly resistant variety of wheat has been of particular value.

Born in Norway, Farstad went, with his family, to America, where he was educated. He obtained his B.Sc. and M.Sc. from the University of Saskatchewan and his Ph.D. from Iowa State College. During this time he began his career as an entomologist in 1929, when he became an assistant in field investigations of grasshopper and cutworms at the Dominion Entomological Laboratory at Lethbridge; in 1945 he became the laboratory's chief. In 1935 he took charge of the work on the control of wheat stem sawfly. By 1946 the first solid stemmed spring wheat variety resistant to sawfly, named "Rescue", was available to farmers. This came out of an accumulation of knowledge and experience built up by Farstad with his assistants; his expertise was recognized when he was made director of the Plant Protection Service in 1959. Here he led the organization which was able to identify the golden nematode on Vancouvor Island and introduce control measures very rapidly in 1965 .

Farstad further contributed to entomology with his activities in tho Entomological Society of Canada, of which ho had been president. He was also a Fellow of the American Society for the Advancement of Science. 